\title{
Possible sources of methane-derived carbon for chironomid larvae
}

\author{
Gundula Eller ${ }^{1}$, Peter Deines ${ }^{1}$, Martin Krüger ${ }^{2, *}$ \\ ${ }^{1}$ Max Planck Institute for Limnology, August-Thienemann-Strasse 2, 24306 Plön, Germany \\ ${ }^{2}$ Geomicrobiology, Federal Institute for Geosciences and Natural Resources, Stilleweg 2, 30655 Hannover, Germany
}

\begin{abstract}
In freshwater food webs, a substantial contribution of methane-derived carbon for the nutrition of larvae of the macroinvertebrate species Chironomus plumosus has been proposed from stable carbon isotope analysis. We investigated if the larvae feed on methanogenic Archaea or methane-oxidising bacteria (MOB), and whether the carbon transfer is based on digestion of the microbial biomass or on a symbiotic relationship. Fluorescence in situ hybridisation (FISH) with larval tissue thin sections showed that the larvae are not inhabited by methanogens or MOB as symbionts or part of their tissue and gut microflora. Furthermore, clone libraries for the bacterial $16 \mathrm{~S}$ rRNA gene from larval tissue and comparative denaturing gradient gel electrophoresis (DGGE) of sediment and larval DNA samples showed that the eubacterial community present in the larval gut is dominated by anaerobic and facultatively anaerobic bacteria, whereas MOB were only rarely found. Additionally, comparative quantitative PCR assays for Eubacteria and Archaea from sediment samples, larval tissue and gut content revealed a strong enrichment of Eubacteria in the larval gut. Consequently, MOB and methanogens were not detected in amounts high enough to explain the larval $\delta^{13} \mathrm{C}$ signatures by direct feeding on their biomass. Thus, the microorganisms might be degraded too fast in the larval gut to be detected by the methods used, or the larvae feed indirectly on MOB- or methanogen-derived carbon, e.g. by feeding on meiofauna which itself is grazing on these microorganisms, or by feeding on organisms growing on MOB-derived carbon metabolites like methanol or carbon dioxide.
\end{abstract}

KEY WORDS: Food web $\cdot$ Chironomid larvae $\cdot$ Symbionts $\cdot$ Methanogenic Archaea $\cdot$ Methanotrophic bacteria

\section{INTRODUCTION}

The carbon flow in freshwater food webs has been intensively studied over the last few decades using stable isotope analysis (e.g. Bunn \& Boon 1993, Jones et al. 1999, France \& Schlaepfer 2000). Interestingly, chironomid larvae (Insecta: Diptera) were often found to be strongly depleted in their biomass ${ }^{13} \mathrm{C}$ content (Bunn \& Boon 1993, Kiyashko et al. 2001, Grey 2002, Grey et al. 2004a,b, Kohzu et al. 2004). These larvae are widespread and often dominate the benthic fauna of lakes (Coffman 1995), providing an important food source for benthic fish. Especially larvae of the species Chironomus plumosus showed strongly ${ }^{13} \mathrm{C}$-depleted signatures, with values ranging from -40 to $-75 \%$ o
(Grey et al. 2004a,b, Kelly et al. 2004, Deines \& Grey 2006, Deines et al. 2007 [this issue]). For larvae with $\delta^{13} \mathrm{C}$ signatures below $-45 \%$, biogenic methane is the only component hitherto known to be depleted enough in its ${ }^{13} \mathrm{C}$ content to be a possible food source for these larvae (Freeman et al. 1990, Hollander \& Smith 2001, Kohzu et al. 2004). Thus, carbon stable isotope analysis led to the hypothesis that these larvae assimilated a dietary food source based on biogenic methane, indicating an unexpected importance of methane-derived carbon for freshwater food webs. Until now, mainly isotopic evidence for this hypothesis has been collected (Bunn \& Boon 1993, Kiyashko et al. 2001, Grey 2002, Grey et al. 2004a,b, Kelly et al. 2004) and not much is known about the uptake mechanism for 
methane-derived carbon by chironomid larvae. Moreover, direct comparisons of the microbial methane cycle and the $\delta^{13} \mathrm{C}$ signature of chironomid larvae are rare (Eller et al. 2005, Deines \& Grey 2006, Deines et al. 2007), but suggest a coupling of methane turnover rates and larval signatures in such a way that higher methane turnover rates lead to more depleted larval $\delta^{13} \mathrm{C}$ signatures. Nevertheless, it has not been possible to relate the larval signatures to either methane production or methane oxidation.

Methane production is a strictly anaerobic process which takes place (e.g.) in anoxic layers of lake sediment and is carried out by methanogenic Archaea. Methanogenic Archaea could be the ${ }^{13} \mathrm{C}$-depleted larval food source since their biomass often is strongly ${ }^{13} \mathrm{C}$ depleted (Fuchs et al. 1979, Belyaev et al. 1983, Balabane et al. 1987). However, the only organisms known to be able to use methane as a carbon source and which are widespread in freshwater environments are aerobic methane-oxidising bacteria (MOB, Hanson \& Hanson 1996). MOB grow preferentially at oxic/ anoxic interfaces where they are provided with methane and oxygen for their metabolism. Larval bioturbating activity (tube dwelling and ventilation) increases the oxic/anoxic boundary layers and the input of oxygen into the otherwise anoxic lake sediment (Frenzel 1990, Granéli 1997). Kajan \& Frenzel (1999) have shown for rice field soil that larval activity increased methane oxidation rates, indicating that the larvae also support MOB growth. Thus, the oxic/ anoxic interface in the larval tube wall could provide an especially suitable microhabitat for $\mathrm{MOB}$ and would alternatively provide the larvae with fresh bacterial (MOB) biomass to feed on.

The carbon transfer from the microorganisms to the chironomid larvae could take place either by feeding on the microbial biomass or by transfer of metabolites from symbiotic Eubacteria/Archaea to their chironomid hosts. Symbiotic relationships between bacteria and animals or protists have been reported for a variety of phyla and systems (Hackstein \& Stumm 1994, Dubilier et al. 1995, Schwarz \& Frenzel 2005, Yang et al. 2005), with methanotrophic symbionts playing an important role in deep-sea environments (Lee \& Childress 1994, Stewart et al. 2005 and references therein). Assuming a similar mechanism as for example in bivalves, symbiotic MOB in chironomid larvae could provide the host with an otherwise unavailable carbon source. The MOB in turn could make use of the larval life in oxic/anoxic boundary layers, where the bacteria would be supplied with both methane and oxygen.

To improve our understanding of the processes underlying the proposed carbon transfer from the microbial methane loop to chironomid larvae, we investigated whether MOB or methanogenic Archaea might be symbionts of chironomid larvae or an important part of the larval diet. For this purpose, we investigated larval tissue and gut content with molecular techniques, including clone libraries, fluorescence in situ hybridisation (FISH) with tissue thin sections, and quantitative PCR (qPCR). Additionally, the eubacterial community structure of the sediment was compared to that of the larval gut content by DGGE, to verify if dominant Eubacteria could be traced from the possible food source sediment into the larvae.

For this study we used larvae of the species Chironomus plumosus, which have been repeatedly reported to have extremely ${ }^{13} \mathrm{C}$-depleted biomass with values below $-45 \%$ (Grey et al. 2004a,b, Kelly et al. 2004, Deines et al. 2007). These larvae exhibit a flexible feeding mode, switching between deposit- and filterfeeding, depending on food availability (McLachlan 1977, Johnson 1985, Berg 1995, Goedkoop et al. 1998). Thus, they could feed on microbial biomass from the sediment as well as from the water directly above the sediment surface, a region in which in many lakes oxic/anoxic interfaces occur, providing the preferred habitat for MOB (Hanson \& Hanson 1996). The larvae were collected from 2 lakes in the Holsteiner lake district, northern Germany (see Table 1). These 2 lakes have been sampled before for comparative studies on the relation between methane turnover rates and larval ${ }^{13} \mathrm{C}$ signatures (Eller et al. 2005, Deines et al. 2007). Deines et al. (2007) found mean $\delta^{13} \mathrm{C}$ values between -43 and $-63 \%$ for larvae from Holzsee throughout $1 \mathrm{yr}$ in contrast to values of around $-30 \%$ for larvae sampled in Großer Binnensee. The stronger ${ }^{13} \mathrm{C}$ depletion for larvae from Holzsee corresponded to higher methane turnover rates. Therefore, we expected higher cell numbers of MOB or methanogens either in the diet or as symbionts in tissue in larvae from Holzsee.

\section{MATERIALS AND METHODS}

Sediment and Chironomus plumosus larvae were sampled from 2 lakes in northern Germany: Großer Binnensee and Holzsee. The lakes and sampling sites have been described in detail in Eller et al. (2005). A short summary of lake characteristics is given in Table 1.

Sampling of larvae and sediment. Sediment for DNA extraction was sampled in May and August 2003 by coring adjacent to the area sampled for chironomid larvae (Eller et al. 2005). Triplicate cores were taken, closed with rubber stoppers and transported to the laboratory immediately after sampling, where they were divided into layers of $0-6,6-12$ and $12-20 \mathrm{~cm}$ sediment depth. The triplicates for each depth layer were 
Table 1. Characteristics of 2 lakes in northern Germany: dimictic Holzsee and polymictic Großer Binnensee (data from Eller et al. 2005). Methane rates averaged over 0 to $12 \mathrm{~cm}$ sediment depths

\begin{tabular}{|c|c|c|c|c|c|c|c|c|}
\hline \multirow[t]{2}{*}{ Lake } & \multirow{2}{*}{$\begin{array}{c}\text { Surface area } \\
\left(\mathrm{km}^{2}\right)\end{array}$} & \multirow{2}{*}{$\begin{array}{l}\text { Max. depth } \\
\text { (m) }\end{array}$} & \multirow{2}{*}{$\begin{array}{l}\text { Mean depth } \\
(\mathrm{m})\end{array}$} & \multirow{2}{*}{$\begin{array}{c}\text { DOC } \\
\left(\mathrm{mg} \mathrm{C} \mathrm{l}^{-1}\right)\end{array}$} & \multicolumn{2}{|c|}{ Methane rates (g dry wt $\mathrm{h}^{-1}$ ) } & \multicolumn{2}{|c|}{$\delta^{13} \mathrm{C}$ content (\%o) of: } \\
\hline & & & & & Production (nmol) & Oxidation ( $\mu \mathrm{mol})$ & Larvae & Sediment \\
\hline Großer Binnensee & 4.8 & 3.0 & 1.9 & 8.2 & 4.6 & 1.4 & $-30.6 \pm 1.4$ & -18.0 \\
\hline Holzsee & 0.2 & 6.9 & 3.7 & 5.0 & 29.3 & 4.4 & $-46.9 \pm 4.1$ & -27.2 \\
\hline
\end{tabular}

combined for further analyses to account for smallscale heterogeneity in the sediment.

Chironomid larvae were collected using an Ekman grab and sieved from the surrounding sediment $(2 \mathrm{~mm}$ mesh) at the lake (Grey et al. 2004b). Sampling water depth was $3 \mathrm{~m}$ in Großer Binnensee and $6.5 \mathrm{~m}$ in Holzsee. Chironomus plumosus 4th instar larvae were selected and transported to the laboratory in lake water.

Fixation of larvae and cleared gut content for FISH. The larvae were either left overnight in $0.2 \mu \mathrm{m}$ filtered tap water at ambient temperature for gut clearance (referred to as larvae without gut content) or directly fixed for FISH (referred to as larvae with gut content). For fixation, the whole larvae were put into $4 \%$ paraformaldehyde for 1 to $3 \mathrm{~h}$ at $4^{\circ} \mathrm{C}$. After washing 3 times for 10 min with PBS, fixed larvae were stored at $4^{\circ} \mathrm{C}$ in $50 \%$ ethanol in PBS (Dubilier et al. 1995).

During gut clearence, faecal material was removed to prevent coprophagy (referred to as cleared gut content). For FISH, cleared gut content was collected from at least 10 larvae per sample and fixed with $4 \%$ paraformaldehyde for $1 \mathrm{~h}$ at room temperature, washed $5 \times$ with PBS and stored in $50 \%$ ethanol in PBS at $-20^{\circ} \mathrm{C}$. For DNA extraction, cleared gut content of 5 larvae per sample was pooled and stored at $-20^{\circ} \mathrm{C}$.

FISH with tissue thin sections and cleared gut content. To localise cells of $\mathrm{MOB}$ and methanogenic Archaea, we applied FISH with probes specific for Eubacteria, MOB and Archaea to tissue thin sections of larvae. After fixation in $4 \%$ para-formaldehyde, larvae were embedded in Technovit 7100 (2- hydroxyethylmethacrylat, Heraeus Kulzer) according to the instructions of the manufacturer. For each sampling date and lake 4 larvae with gut content and 4 larvae without gut content were embedded, sliced and analysed by FISH. Two larvae of these sets were sliced longitudinal, and the other two vertical, to the larval body axis to better cover different parts of the larval tissue during analysis. Slices of $4 \mu \mathrm{m}$ thickness were cut with a microtome (RM 2165, Leica) and mounted onto poly-L-lysin (Sigma-Aldrich) coated slides, dried on a hot plate at $60^{\circ} \mathrm{C}$ for $1 \mathrm{~h}$ and stored dust free at room temperature. Before FISH, tissues were re-hydrated in absolute, 80 and $50 \%$ ethanol for $10 \mathrm{~min}$ each at room temperature, treated with $0.2 \mathrm{~N} \mathrm{HCl}$ (12 min room temperature), washed with $20 \mathrm{mM}$ Tris/ $\mathrm{HCl}$ pH 8.0 (10 min room temperature) and incubated with Proteinase $\mathrm{K}$ for $30 \mathrm{~min}$ at $37^{\circ} \mathrm{C}$ as described by Dubilier et al. (1995). Hybridisation was carried out for $3 \mathrm{~h}$ at $46^{\circ} \mathrm{C}$ as described in Eller et al. (2005), with buffer volumes adapted to cover the whole slice. Probes Eub338 I and Arch915 for Eubacteria and Archaea (Amann et al. 1990) were used in addition to a mixture of Probes Mr84/Mr705 to target Type I MOB (Methylococcaceae) and Probe M $\gamma 450$ to target Type II MOB (Methylocystaceae) (Eller et al. 2001).

Samples of cleared gut content of chironomid larvae were embedded in agarose and hybridised as described in Eller et al. (2005) with the abovementioned probe sets. For amplification of the fluorescence signal by catalysed reporter deposition (CARD-FISH), the protocol described by Pernthaler et al. (2002) was followed, using a hybridisation temperature of $37^{\circ} \mathrm{C}$. Slides were analysed using a Zeiss axioplan 2 microscope (Zeiss), equipped with a $100 \times$ oil immersion lens, $1.25 \times$ Optovar and F-view digital black and white camera. AnalySIS 3.0 software (Soft Imaging System) was used for image analysis.

DNA extraction, PCR amplification and clone libraries. From larval tissue and gut content, DNA was extracted using the DNeasy tissue kit (QIAGEN). The extraction started with tissue lysis with Proteinase K overnight and was continued following the instructions of the manufacturer. For the analysis of larval tissue, DNA of 5 larvae per sample was pooled. The mixed gut content of 5 larvae was collected for DNA extraction.

For each sediment sample analysed, the triplicate core sections of each depth layer were combined. DNA was extracted from sediment samples by cell lysis with $10 \%$ lauryl-sulphate solution $(10 \%$ SDS in $0.5 \mathrm{M}$ Tris/ $\mathrm{HCl}, \mathrm{pH} 8.0,0.1 \mathrm{M} \mathrm{NaCl}$ ) and horizontal shaking for $45 \mathrm{~s}$ (Vortex Genie 2 with adapter 13000-V1, MoBio Laboratories) after addition of zirconium-silica beads, followed by DNA purification using $\mathrm{NH}_{4}$-acetate and isopropanol precipitations as described in detail by Henckel et al. (1999).

For clone libraries, 16S rRNA genes of Eubacteria were selectively amplified from bulk DNA using primers GM3 f (AGA GTT TGA TCM TGG C; Escherichia coli Positions 8 to 24; Muyzer et al. 1993) and GM4 r (TAC CTT GTT ACG ACT T; E. coli Positions 1492 to 1507 ; Kane et al. 1993), synthesised by MWG-Biotech. Poly- 
merase chain reactions were performed in a Mastercycler Gradient (Eppendorf) as follows: $94^{\circ} \mathrm{C}$ for $3 \mathrm{~min}$, 28 cycles of $94^{\circ} \mathrm{C}$ for $1 \mathrm{~min}, 48^{\circ} \mathrm{C}$ for $1.5 \mathrm{~min}, 72^{\circ} \mathrm{C}$ for $2 \mathrm{~min}$ and a final extension period of $6 \mathrm{~min}$ at $72^{\circ} \mathrm{C}$.

PCR products were purified using the QIAQuick PCR purification kit (QIAGEN) and cloned using the TOPO TA Cloning ${ }^{\circledR}$ kit (pCR ${ }^{\circledR} 4-\mathrm{TOPO}^{\circledR}$ suicide vector) according to the manufacturer's specifications (Invitrogen). Clone libraries were constructed by transforming Escherichia coli TOP10F cells. In order to reduce cloning biases, clones of several parallel cloning experiments were combined to construct each library. Plasmid DNA from each clone was extracted from $2 \mathrm{ml}$ overnight cultures using the QIAprep ${ }^{\circledR}$ miniprep kit (QIAGEN) according to the manufacturer's recommendations. Plasmids were checked for the presence of correct size inserts on agarose gels, and then used as template for sequencing. Inserts were sequenced by Taq cycle on an ABI 3100 sequencer (Applied Biosystems), using the following primers: 8f (5'-GCG CCA GCA GCC GCG GTA A-3') and Uni 1392r (ACG GGC GGT GTG TRC, 32) for the bacterial 16S rRNA genes.

Quantification of 16S rRNA genes. We used quantitative PCR analysis (qPCR) to enumerate the 16S rRNA genes of Eubacteria and Archaea in all samples of sediment, larval tissue and gut content. Real-time PCR was carried out using an ABI Prism 7000 sequence detection system (Applied Biosystems), following the protocol of Lüders et al. (2004) with the primer sets Ba519f/Ba907r and Ar109f/Ar912r for Eubacteria and Archaea, respectively. The gene copy numbers were converted into cell numbers using a conversion factor of 3.6 and 1 for Eubacteria and Archaea, respectively (Klappenbach et al. 2001).

DGGE and sequence analysis. Prior to DGGE, the 16S rRNA gene of Eubacteria was amplified using a universal eubacterial primer set (533f-GC / 907r, Weisburg et al. 1991), with a GC-clamp attached to the 5 '-end of the forward primer. The PCR protocol and primers have been described in detail by Henckel et al. (1999). DGGE analysis was carried out as described by Henckel et al. (1999) at $60^{\circ} \mathrm{C}$ and $150 \mathrm{~V}$ for $5 \mathrm{~h}$ (Dcode System, BioRad). Denaturing gradients from 35 to $70 \%$ were used, with $80 \%$ corresponding to $6.5 \%$ acrylamide, 5.6 M urea and $32 \%$ deionised formamide. Gels were stained after the run with SYBR-Gold (Molecular Probes, supplied by Biozym), 1:10000 diluted in Tris/ EDTA-buffer (10 mM Tris, 1 mM EDTA, pH 8.0) for $45 \mathrm{~min}$ in the dark. DGGE bands were illuminated using a Dark Reader transilluminator (Clare Chemical Research), excised, suspended in $200 \mu \mathrm{l}$ PCR grade water and stored at $-20^{\circ} \mathrm{C}$. Prior to the first reamplification PCR, bands were left at room temperature for 30 min to allow diffusion of the DNA from the polyacrylamide gel into the water. Band purity was con- trolled by reamplification and subsequent DGGE. Only reamplification products which resulted in 1 single band with the predicted electrophoretic mobility were sequenced. MOB pure cultures of the genera Methylobacter, Methylomonas and Methylocystis were used as positive controls and markers for band mobility.

For sequencing, PCR products were purified using QIAQuick PCR purification columns (QIAGEN). Sequencing reactions were performed using the $\mathrm{ABI}$ PRISM BigDye Terminator v3.1 Cycle Sequencing Kit (Applied Biosystems), following the instructions of the manufacturer. Cycle sequencing products were analysed with an ABI PRISM 3100 Genetic Analyzer (Applied Biosystems). All sequences were analysed using the CodonCodeAligner software package (Version 1.4.6, CodonCode), checked for next relatives by BLAST search in the recent GenBank Data Library (www.ncbi.nlm.nih.gov/BLAST/), and aligned and phylogenetically analysed with the ARB software package (Ludwig et al. 2004). The ARB database used was based on the ssuJan03 database and updated with sequences of interest from GenBank, containing approximately 26000 sequences in total.

Nucleotide accession numbers. All sequence data have been submitted to the EMBL database (www.ebi.ac.uk) under Accession Nos. AM418932AM419006, AM422217-422369, and AM422520422555 for clone sequences and AM422610AM422684 for sequences of DGGE bands.

\section{RESULTS}

\section{FISH with larval tissue and gut content}

To localise cells of MOB and methanogenic Archaea in the larval tissue, we applied FISH to tissue thin sections of larvae. These analyses were of qualitative nature, to test whether a symbiosis between the larvae and $\mathrm{MOB}$ or methanogens might be possible. With this method, microcolonies of Eubacteria were detected on the body surface of the larvae. Additionally, single eubacterial cells occurred within the larval tissue. Nevertheless, highest numbers of Eubacteria were present in the larval gut, and high numbers were also regularly detected in the cleared gut content. However, MOB were only rarely detected. In larval tissue, only cells belonging to Type I MOB (no Type II) were found. All Type I MOB cells were present in the larval gut, not in the larval tissue itself or on the larval body surface. MOB occurred more regularly than Archaea in the gut, but compared to the number of Eubacteria their number was low $(<1 \%)$. Nevertheless, MOB could be cultivated from cleared larval gut content (G. Eller \& P. Deines unpubl. data) and were also detected 
by FISH in the cleared gut material, indicating that MOB were regularly present in the gut content.

Archaea were only seldomly detected in tissue thin sections, and in these only in the gut. The archaeal cells detected were small and occurred as single cells, not in microcolonies. These low numbers of Archaea in the larval gut were confirmed with the highly sensitive FISH with signal amplification by the catalysed reporter deposition method (CARD-FISH) in samples of cleared gut content.

\section{Characterisation of Eubacteria associated with chironomid larvae}

Clone libraries for the eubacterial 16S rRNA gene were made from DNA of larval tissue and gut content to find the dominant groups of Eubacteria associated with the larvae and to test whether hitherto not known methanotrophs (which might not be covered with the 16S rRNA probes used for FISH) were present. Clone libraries were made for samples obtained in May 2003 from pooled DNA preparations of 5 larvae without gut content per lake and the DNA extracted from cleared gut content itself, also from 5 larvae (Table 2). Even though cloning was carried out repeatedly, only low numbers of clones with inserts of the right length were achieved per sample. Nevertheless, rare fraction analysis illustrated that the diversity of Eubacteria present was not undersampled in the larvae.

For larvae without gut content from Großer Binnensee, $41 \%$ of eubacterial clone sequences clustered with Bacteroides, especially Dysgonomonas $(17 \%$ of all clones, similarity 91 to $93 \%$ ) and Rikenella (16\% of all clones, similarity 88 to $92 \%$ ), followed by $21 \%$ Enterobacteriaceae, and 14\% Desulfobacteriaceae (Table 2). No clone belonging to methano- or methylotrophic groups was detected in this sample. Only in the cleared gut content from larvae collected in Großer Binnensee did $2.8 \%$ of the clones (2 out of 72 clones) cluster with Type I MOB, 1 of these with Methylocaldum (94 to $95 \%$ similarity) and 1 with Methylomicrobium (90 to $92 \%$ similarity, Table 2 ).

For DNA extracted from larvae without gut content from Holzsee, $32 \%$ of the clone sequences clustered with Fusobacterium (similarity 86 to $92 \%$ ), and almost equal amounts of clones $(10 \%)$ clustered with Clostridia, Bacteroides and Desulfobacteriaceae (Table 2). Again, sequences related to $\mathrm{MOB}$ or methylotrophic bacteria were only found in the cleared gut content, with $2.1 \%$ (1 out of 47 clones) each for Hyphomicrobium (82\% similarity), Methylobacillus/Methylophilus (92 to $95 \%$ similarity) and Methylobacter (96 to $97 \%$ similarity).

\section{Quantification of Eubacteria and Archaea in sediment and chironomid larvae}

Numbers of Eubacteria and Archaea were determined by qPCR in larval tissue and sediment samples to verify if a symbiotic relationship between larvae and methanogens or MOB or selective feeding of the larvae on methanogens or MOB led to an enrichment of the respective microbial group in the larvae. For both lakes and both sampling time points, in the DNA

Table 2. Eubacteria 16S rRNA gene clone library for DNA extracted from chironomid larval tissue and cleared gut content, sampled from Großer Binnensee and Holzsee in May 2003. Given are percentages of the total. Larva -GC: larvae without gut content (larval tissue extracted after gut clearance); Larva +GC: larvae with gut content (larval tissue extracted without preliminary gut clearance). Sum of minor clone groups in the respective higher taxonomic groups are shown in bold

\begin{tabular}{|c|c|c|c|c|c|c|c|}
\hline \multirow{2}{*}{$\begin{array}{l}\text { Taxonomic } \\
\text { group }\end{array}$} & \multirow{2}{*}{$\overline{\text { Gut content }}$} & \multicolumn{2}{|c|}{ Großer Binnensee } & \multirow[b]{2}{*}{ Gut content } & \multirow{2}{*}{$\overline{\text { Larva }-\mathrm{GC}}$} & \multirow{2}{*}{$\begin{array}{l}\text { Lolzsee } \\
\quad \text { Larva }+\mathrm{GC}\end{array}$} & \multirow[b]{2}{*}{ Sum all samples } \\
\hline & & Larva-GC & Sum all samples & & & & \\
\hline 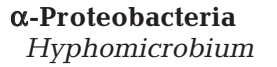 & 6.9 & $\mathbf{0}$ & 3.4 & 2.1 & 5.3 & 2.9 & $\begin{array}{l}2.5 \\
0.8\end{array}$ \\
\hline $\begin{array}{r}\boldsymbol{\beta} \text {-Proteobacteria } \\
\text { Methylobacillus }\end{array}$ & 11.1 & 4.0 & 7.4 & $\begin{array}{c}\mathbf{1 0 . 6} \\
2.1\end{array}$ & $\mathbf{0}$ & $\mathbf{0}$ & $\begin{array}{l}\mathbf{5 . 0} \\
0.8\end{array}$ \\
\hline$\gamma$-Proteobacteria & & & & & $\mathbf{0}$ & $\mathbf{0}$ & \\
\hline Enterobacteriaceae & 12.5 & 21.1 & 16.9 & 6.4 & & & 2.5 \\
\hline Methylocaldum & 1.4 & & 0.7 & & & & \\
\hline Methylomicrobium & 1.4 & & 0.7 & & & & \\
\hline Methylobacter & & & & 2.1 & & & 0.8 \\
\hline$\delta$-Proteobacteria & 20.8 & 14.5 & 17.6 & 10.6 & 10.5 & 17.1 & 12.5 \\
\hline Clostridia & 8.3 & 10.5 & 9.5 & 14.9 & 7.9 & 22.9 & 15.0 \\
\hline Bacteroides & 12.5 & 40.8 & 27.0 & 8.1 & 10.5 & 25.7 & 14.2 \\
\hline Fusobacteria & 11.1 & 2.6 & 6.8 & 4.3 & 31.6 & 22.9 & 18.3 \\
\hline Other & 13.9 & 6.6 & 10.1 & 22.7 & 29.0 & 8.6 & 22.5 \\
\hline Total no. of clones & 72 & 76 & 148 & 47 & 38 & 35 & 120 \\
\hline
\end{tabular}



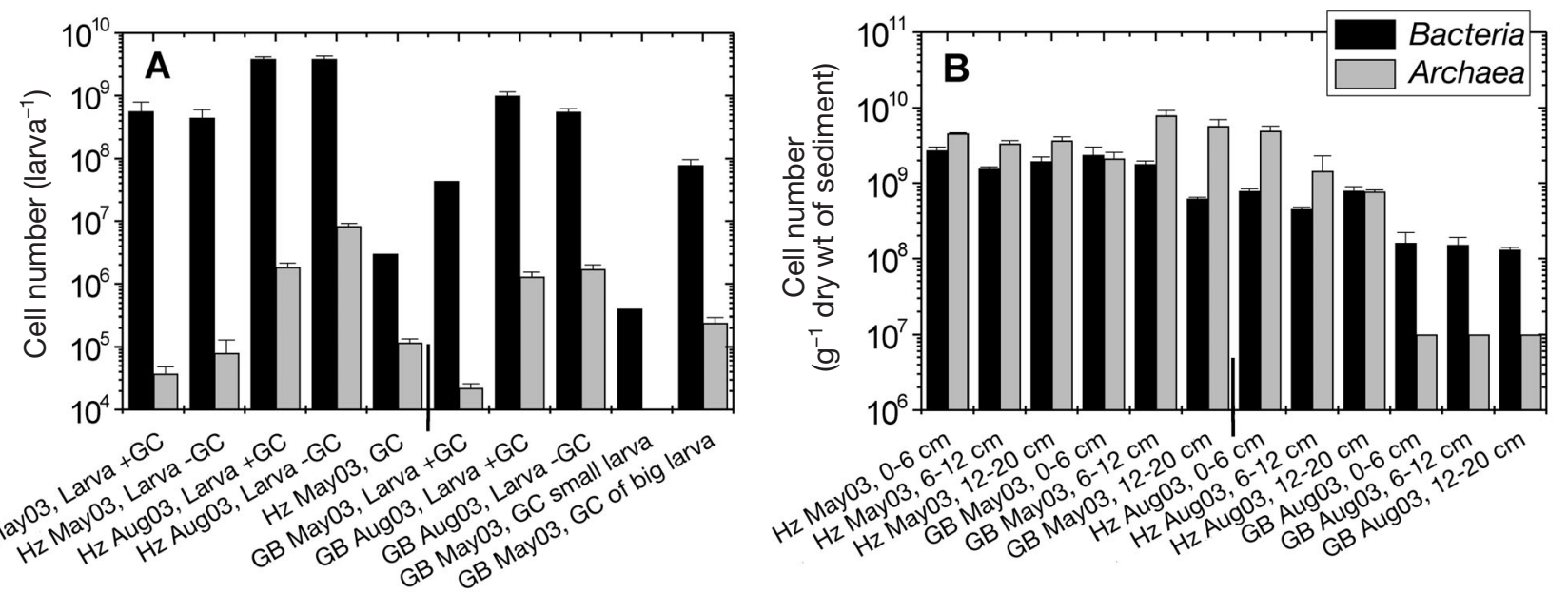

Fig. 1. Archaea and Eubacteria quantified in (A) samples of larval tissue and gut content by quantitative PCR (qPCR) and (B) sediment samples taken from Großer Binnensee and Holzsee in March and August 2003. Error bars = SE of qPCR. GB: Großer Binnensee; Hz: Holzsee; GC: gut content; +GC: with gut content; -GC: without gut content; 0-6, 6-12, 12-20 cm: respective sediment layers

extracted from larvae and larval gut content a clear dominance of Eubacteria over Archaea by 2 to 4 orders of magnitude was detected by qPCR (Fig. 1A). Both microbial groups showed increasing cell numbers from May to August in the larval DNA samples. A comparison of the 2 lakes showed that slightly higher numbers of Eubacteria were detected in larval material from Holzsee.

In contrast to the larval tissue and gut content in sediment samples from May 2003, a strong dominance of Archaea was found for both lakes, which continued for Holzsee sediment in August 2003 (Fig. 1B).

\section{Comparison of eubacterial diversity in sediment samples and larvae by PCR-based DGGE}

To verify whether the eubacterial community in DNA extracted from larval material resembled the community present in the bulk sediment, DGGE was carried out after amplification of the 16S rRNA gene of Eubacteria. In both lakes a higher number of bands occurred in larval DNA samples from May than in samples from August, but major bands were similar (Fig. 2). Several bands with similar mobility were detected for larval samples from the 2 lakes. The sequences of



Fig. 2. Comparison of eubacterial communities in sediment samples and chironomid larval tissue in the 2 lakes, Großer Binnensee and Holzsee, in May and August 2003 after amplification of the 16S rRNA gene. Phylogenetic affiliations of sequenced bands (marked with circles) are given in Table 3. Band numbering begins at left side of the gels, with the lowest numbers at the top of each lane. Methanotroph pure cultures were used as references for band mobility. GB: Großer Binnensee; Hz: Holzsee; Sed: sediment; Larvae: chironomid larvae; +GC: with gut content; - GC: without gut content; GC: gut content 
Table 3. Affiliation of DGGE band sequences derived after amplification of the eubacterial 16S rRNA gene from DNA extracted from sediment and larval tissue and gut content sampled in May and August 2003 in Großer Binnensee and Holzsee

\begin{tabular}{|c|c|c|}
\hline DGGE Band No. (Fig. 2) & Higher group & Next known relative (range of similarity, \%) \\
\hline $3,4,17,20,26,35,39,41,49,71$ & Bacteroides & Dysgonomonas (91-97\%) \\
\hline $5,6,7,27,37,50$ & Bacteroides & Rikenella (85-93\%) \\
\hline $15,16,30,31,65$ & Bacteroidales & Uncultured (within larval clone-cluster) \\
\hline $8,11,18,21,22,23,24,48,51,52$ & Clostridia & Chlostridium (92-99\%) \\
\hline $42,66,67,72$ & Fusobacteria & Fusobacterium (91-96\%) \\
\hline $10,29,38,44,45$ & & Thiotrix $(76-90 \%)$ \\
\hline $1,2,56$ & & Achromatium (86-92\%) \\
\hline $46,47,53,54$ & Synechococcus et rel. & $(89-98 \%)$ \\
\hline $68,69,70$ & $\begin{array}{l}\text { Geobacteraceae, } \\
\text { Desulfuromonadales }\end{array}$ & $(87-96 \%)$ \\
\hline $59,62,63$ & $\delta$-Proteo & Syntrophus (93-94\%) \\
\hline $9,25,74$ & Sphingobacteraceae & (within larval clone cluster, 88-92\%) \\
\hline 12 & $\gamma$-Proteo & Marinobacter (92-93\%) \\
\hline 14 & $\gamma$-Proteo & Aeromonas jandaei (100\%) \\
\hline 36 & $\alpha$-Proteo & Hyphomicrobium vulgare (88\%) \\
\hline 19 & $\delta$-Proteo & Desulfobacteraceae (92-94\%) \\
\hline 73 & Acidaminococcaceae & Succinispira mobilis (97\%) \\
\hline 75 & $\beta$-Proteo & Iodobacter fluviatilis (91\%) \\
\hline $13,28,32,33,34,40,43,55,57,58,60,61,64$ & Other & \\
\hline
\end{tabular}

these bands clustered together with some of the most numerous groups detected in clone libraries, e.g. Dysgonomonas and Fusobacterium (Tables 2 \& 3, Fig. 2). In agreement with the clone library results, only the sequence of 1 single and faint DGGE band from larval tissue clustered within the methylotrophic genus Hyphomicrobium (88\% similarity, Table 3).

For all sediment samples, banding patterns were very weak, but showed no changes between the sampling time points. Only a few sequences were obtained for sediment samples and none of these clustered together with any of the sequences derived from larval samples (Fig. 2, Table 2). Additionally, overall banding patterns in sediment and larval samples were clearly different.

\section{DISCUSSION}

\section{Do chironomid larvae feed on methanogenic Archaea?}

The importance of a carbon source for the nutrition of the larvae can be estimated using its $\delta^{13} \mathrm{C}$ signature. However, in sediments the biomass $\delta^{13} \mathrm{C}$ signatures of the potential larval food sources MOB and methanogenic Archaea are hidden in the bulk sediment $\delta^{13} \mathrm{C}$ signature, which reflects the sum of all sedimented organic material, recalcitrant compounds and microbial biomass. Therefore, we had to estimate the biomass signatures of methanogens from the signatures of their carbon substrates.

For the 2 lakes investigated here, a dominance of hydrogenotrophic methanogenesis has been reported (Eller et al. 2005). Additionally, in clone libraries for the $\alpha$-subunit of the methanogenic key enzyme methylcoenzyme $\mathrm{M}$ reductase, we found sequences related to Methanomicrobiales (which are predominantly hydrogenotrophic) to be dominant in both lakes (M. Krüger \& G. Eller unpubl. data). The carbon source for this group of methanogens is carbon dioxide, which showed $\delta^{13} \mathrm{C}$ signatures around $-10 \%$ in April and $-27 \%$ in August 2004 in pore water samples from both Holzsee and Großer Binnensee. For hydrogenotrophic methanogens, fractionation factors from substrates to biomass of -2 to $-27 \%$ were reported (Belyaev et al. 1983, Balabane et al. 1987, House et al. 2003). Based on the carbon dioxide signatures and applying the strongest isotope effect reported for hydrogenotrophic methanogens $(-27 \%)$, the methanogenic biomass in the 2 lakes could reach $\delta^{13} \mathrm{C}$ values of $-54 \%$. For the sediment of Großer Binnensee and Holzsee, $\delta^{13} \mathrm{C}$ signatures of -18 and $-27 \%$ were reported in August 2003 (Eller et al. 2005). At the same time, the larval biomass showed $\delta^{13} \mathrm{C}$ signatures of -31 and $-47 \%$, respectively (Eller et al. 2005). To estimate the importance of methanogens relative to bulk sediment for the larval diet, the abovementioned $\delta^{13} \mathrm{C}$ signatures were used in a 2 source isotope mixing model calculation (Phillips \& Gregg 2001). This calculation revealed that at least $50 \%$ of the larval carbon source must have been derived from methanogens. Consequently, methanogens should reach $50 \%$ of the total number of microorganisms present in the gut content.

However, Archaea were not detected in high numbers in larval tissue and gut content, even though FISH and the highly sensitive CARD-FISH were used. Nevertheless, we cannot entirely exclude a rapid 
digestion of archaeal cells, preventing their detection by FISH and DNA based methods. The high numbers of Archaea found in the sediment by qPCR were not detected in the larval tissue. Furthermore, the relative contribution of Archaea and Eubacteria to total microbial cell numbers was inverted for samples of bulk sediment compared to samples of larval tissue and gut content (Fig. 1), indicating an enrichment of Eubacteria (not Archaea), e.g. by selective feeding in the larvae. Therefore, it is unlikely that the larvae reach the ${ }^{13} \mathrm{C}$ depletion reported for their biomass by feeding on methanogens. Regarding the high numbers of Archaea in lake sediments in contrast to the low numbers found in chironomid larvae, the larvae could feed in microniches of the sediment in which Archaea are less abundant. Another possibility might be the growth of Eubacteria in the larval gut and the establishment of a gut microflora dominated by Eubacteria.

\section{Relationship between MOB and chironomid larvae}

As an alternative to methanogenic Archaea, MOB growing on biogenic methane as a carbon source are also a likely methane-linked food source for chironomid larvae. Eller et al. (2005) used methane, sediment and larval $\delta^{13} \mathrm{C}$ signatures to calculate the theoretical importance of MOB for the larval diet in Großer Binnensee and Holzsee in August 2003 with the 2 source isotope mixing model of Phillips \& Gregg (2001). For this calculation, Eller et al. (2005) applied fractionation factors of -16 and $-30 \%$ for the conversion of methane to Type I MOB biomass (Summons et al. 1994, Jahnke et al. 1999) and calculated the contribution of MOB biomass needed in the larval diet to be 16 to $20 \%$ and 24 to $29 \%$ in Großer Binnensee and Holzsee, respectively. Thus, the larvae would need to take up less biomass of MOB than of methanogens to reach their depleted $\delta^{13} \mathrm{C}$ signature.

However, in clone libraries of the eubacterial 16S rRNA gene derived from the larval gut content, only 2 to $3 \%$ of the sequences were related to $\mathrm{MOB}$ in both lakes. This discrepancy with the model calculation, which predicted more than $15 \%$ MOB contribution, could be due to a rapid digestion of MOB cells within the larval gut. Kiyashko et al. (2004) demonstrated the presence of phospholipid fatty acids specific for Type I MOB in chironomid larvae collected in Lake Biwa, indicating that the larvae indeed ingested substantial amounts of MOB biomass. However, our results seem not to support the hypothesis of Grey et al. (2004b) that chironomid larvae feed directly on MOB biomass.

Theoretically, one can also speculate whether an alternative to the direct uptake of methane-derived carbon via MOB biomass might be the fact that the larvae feed predominantly on autotrophic microorganisms fixing $\mathrm{CO}_{2}$ released by MOB or even on methylotrophic microorganisms like Hyphomicrobium, which use methanol or other carbon metabolites released by MOB. The larval $\delta^{13} \mathrm{C}$ signatures of -46 to $-55 \%$ in Holzsee in August 2003 (Eller et al. 2005) indicate a methanederived carbon source, because $\mathrm{CO}_{2}$ recycling in general usually results in $\delta^{13} \mathrm{C}$ signatures not lower than -40 to $-45 \%$ (Freeman et al. 1990, Hollander \& Smith 2001). However, this methane-derived carbon source does not need to be MOB biomass, but could also be biomass of autotrophic bacteria, which assimilate the $\mathrm{CO}_{2}$ released by MOB (Kohzu et al. 2004). These autotrophic microorganisms growing close to MOB on the ${ }^{13} \mathrm{C}$-depleted methane-derived $\mathrm{CO}_{2}$ should have a more negative biomass $\delta^{13} \mathrm{C}$ than would be expected for autotrophic bacteria growing on recycled photosynthetic $\mathrm{CO}_{2}$. Based on the high inter-individual variability found for sulphur, carbon and nitrogen stable isotope signatures in Chironomus plumosus larval biomass, Grey \& Deines (2005) hypothesised that individual larvae feed on MOB and chemoautotrophic bacterial biomass in different amounts. Nevertheless, no sequences belonging to these autotrophic groups were detected in our study. Instead, sequences of methylotrophic organisms were detected by DGGE and in clone libraries, indicating that this group of microorganisms might be important for the larval diet.

Another possible explanation for the discrepancy between the proportion of MOB in the larval diet calculated by the 2-source isotope mixing model and detected by FISH and clone libraries is larval feeding on protists that have ingested MOB or methanogens and therefore exhibit a strongly ${ }^{13} \mathrm{C}$-depleted carbon signature. Feeding of protists on (e.g.) methanogens has recently been reported for rice field soil (Schwarz \& Frenzel 2005) and could occur in lake sediments too. Because microbial cells would already be digested within the protists, MOB and methanogens would not be detectable in the larval gut by our methods, but the $\delta^{13} \mathrm{C}$ signature of the strongly ${ }^{13} \mathrm{C}$-depleted carbon source would be 'transported' to the larvae also.

For zooplankton communities (e.g.) Jones et al. (1999) proposed, based on stable carbon isotope analysis, that MOB as methane-derived carbon source contribute to the nutrition of several taxa. This hypothesis was proved by comparative analysis of $\delta^{13} \mathrm{C}$ signatures and bacterial production by Bastviken et al. (2003). Nevertheless, Lennon et al. (2006) found a stronger correlation between the $\delta^{13} \mathrm{C}$ of particulate organic matter and zooplankton and the concentration of terrestrial dissolved organic carbon than to the methane concentrations and cell numbers of methanogens and MOB. Thus, it seems to be possible that zooplankton species feed on methane-derived carbon via MOB biomass, 
but the extent of this nutrition depends on the special conditions present in the respective lake.

The above hypotheses of indirect larval feeding on a methane-derived carbon source indicate that the 2 source isotope mixing model used in our and other studies (Kelly et al. 2004, Eller et al. 2005, Deines \& Grey 2006) is not sufficient to calculate the contribution of these microorganisms to the larval diet, as most probably a mixture of direct assimilation of MOB/ methanogen biomass and the assimilation of organisms feeding on MOB or their metabolites leads to the larval signature.

A completely different explanation for the discrepancy in relative MOB gene abundance and the high calculated contribution of $\mathrm{MOB}$ to the strongly negative $\delta^{13} \mathrm{C}$ of larval biomass is a symbiotic relation between $\mathrm{MOB}$ and larvae, as often observed in chemosynthetic deep sea communities (Lee \& Childress 1994, Stewart et al. 2005 and references therein). However, for the chironomid larvae, FISH with thin sections of larval tissue and MOB-specific probes revealed that MOB were only present in the gut and not in the tissue itself or on the larval body surface. Additionally, even in the gut MOB were only found in low numbers and not in all samples analysed, indicating that they were not part of the regular gut microflora of the larvae. A parallel analysis of the microhabitat 'chironomid larval gut' by microelectrode measurements for oxygen, $\mathrm{pH}$ and redox potential revealed a gut content $\mathrm{pH}$ of 8 , but anoxic conditions within the gut (Stief \& Eller 2006). Thus, even though the $\mathrm{pH}$ in the gut was suitable for $\mathrm{MOB}$, the anoxic conditions would prevent growth of MOB with methane as carbon source. These findings agree well with the clone libraries and DGGE analysis, which revealed a dominance of sequences belonging to groups of anaerobic and facultatively anaerobic bacteria in the eubacterial community detected in the larval gut content. Moreover, the high inter-individual variability in larval $\delta^{13} \mathrm{C}$ signatures found in Holzsee (Deines et al. 2007) indicate that the contribution of methane-derived carbon to the larval nutrition varies strongly, ruling out that the relationship between larvae and bacteria is an obligate symbiosis (Kiyashko et al. 2001).

Summarising all these results, we did not find indications for direct feeding of the larvae on MOB or methanogen biomass or a symbiotic relation between the larvae and MOB or methanogens.

\section{Do chironomid larvae feed on the microbial community in the bulk sediment?}

If the larvae feed unselectively on all microbial biomass present in the bulk sediment and no microbial proliferation occurs in the gut, the relative abundance of 16S rRNA genes for the Eubacteria and Archaea present in their gut contents should resemble that in the sediment. However, the qPCR revealed an inversion of the relative abundance of Archaea and Eubacteria from sediment to larval tissue and gut content in May 2003. Additionally, the DGGE analysis revealed substantial differences in the community structure of Eubacteria between sediment and larval samples (Fig. 2), indicating that not only the cell numbers, but also the composition of the eubacterial community was influenced by the larvae. This could either be due to the larval influence on the microbial community present in the sediment of the larval tubes or to the establishment of a special gut microflora. The bioturbation and bioirrigation of the larvae lead to the establishment of microhabitats with specialised microbial populations (Johnson et al. 1989, Svensson 1997, Kajan \& Frenzel 1999, Stief \& de Beer 2002), which should represent the microbial food source for the larvae. Unfortunately, in natural environments it is very difficult to sample sediment from larval tubes, thus preventing a direct comparative analysis of the hypothesised microbial food source and the larval gut content. Nevertheless, the strong quantitative and qualitative differences detected between larval material and bulk sediment indicate that, due to their 'life style', the larvae support or promote the growth of microorganisms in their surroundings, which then are part of their diet. Additionally, the gut transfer itself most likely influences the composition of the microbial community, leading to activation or inactivation of special groups of microorganisms associated with the gut content. Consequently, this causes the establishment of a specialised gut microflora, as observed for example in termites or beetle larvae (Egert et al. 2003, Schmitt-Wagner et al. 2003), which seems in the anaerobic environment of the chironomid gut to be dominated by (facultatively) anaerobic Eubacteria (discussed in detail in Stief \& Eller 2006).

Besides the differences between sediment and larval samples, the total cell numbers detected in sediment sampled in August 2003 were (especially for Großer Binnensee) much lower than the numbers detected in May (Fig. 1). This could have been due to an increased grazing pressure on the microbial community in the summer, and increasing oxygen limitation (especially in the deeper sediment layers) at the end of the summer period. The parallel increases in cell numbers of Eubacteria and Archaea in the larval samples from both lakes support this hypothesis of increased grazing pressure, and indicate that seasonal changes detected in $\delta^{13} \mathrm{C}$ signatures of larval tissue (Grey et al. 2004b) might indeed be connected to changes in the importance of microorganisms in general for the nutrition of chironomid larvae. 


\section{CONCLUSIONS}

In conclusion, no indication for a symbiosis of chironomid larvae with MOB or methanogenic Archaea was detected, which might have explained the strongly negative, methane-related $\delta^{13} \mathrm{C}$ signatures of the larval biomass. The comparison of the microbial community of larval tissue and gut contents with the bulk sediment samples showed substantial differences. Furthermore, the molecular analysis demonstrated that both MOB and Archaea represent only a very small fraction of microorganisms in the larval gut contents. The larval gut is dominated by anaerobic and facultatively anaerobic Eubacteria. Consequently, either methanogens and MOB have been degraded rapidly after consumption, thus escaping molecular analysis, or the larvae do not feed directly on these microorganisms. Instead, it might be possible that either methylo- or autotrophic microorganisms feed on carbon metabolites released by $\mathrm{MOB}$ (like $\mathrm{CO}_{2}$ or methanol) or that members of the meiofauna (such as ciliates) feed on MOB or methanogen biomass (Schwarz \& Frenzel 2005). These microorganisms or protists are then, in turn, taken up by the grazing chironomid larvae, indirectly transferring the methane $\delta^{13} \mathrm{C}$ signature into the larvae.

Acknowledgements. We are grateful for technical assistance in the laboratory from I. Schultz, C. Schleker, N. Ryk, T. Sonntag, R. Appel, S. Seeland, C. Haveland, A. Lepler and A. Schippers. N. Dubilier and her group gave a very helpful introduction to FISH with tissue thin sections. We thank the anonymous referees for critical comments on earlier drafts of the manuscript. Graf Waldersee and F. Schrage provided access to Großer Binnensee and Holzsee, respectively. Financial support came from the Max Planck Society and the Federal Institute for Geosciences and Natural Resources.

\section{LITERATURE CITED}

Amann RI, Binder BJ, Olson RJ, Chisholm SW, Devereux R, Stahl DA (1990) Combination of 16S rRNA-targeted oligonucleotide probes with flow cytometry for analyzing mixed microbial populations. Appl Environ Microbiol 56: 1919-1925

Balabane M, Galimov E, Hermann M, Létolle R (1987) Hydrogen and carbon isotope fractionation during experimental production of bacterial methane. Org Geochem 11: 115-119

Bastviken D, Ejlertsson J, Sundh I, Tranvik L (2003) Methane as a source of carbon and energy for lake pelagic food webs. Ecology 84:969-981

Belyaev SS, Wolkin R, Kenealy WR, DeNiro MJ, Epstein S, Zeikus JG (1983) Methanogenic bacteria from the Bondyuzhskoe oil field: general characterization and analysis of stable-carbon isotopic fractionation. Appl Environ Microbiol 45:691-697

Berg MG (1995) Larval food and feeding behaviour. In: Armitage PD, Cranston PS, Pinder LCV (eds) The Chi- ronomidae: biology and ecology of non-biting midges Chapman \& Hall, London, p 1-54

Bunn SE, Boon PI (1993) What sources of organic carbon drive food webs in billabongs? A study based on stable isotope analysis. Oecologia 96:85-94

Coffman WP (1995) Conclusions. In: Armitage PD, Cranston PS, Pinder LCV (eds) The Chironomidae: biology and ecology of non-biting midges. Chapman \& Hall, London, p 297-338

Deines P, Grey J (2006) Site specific methane production and subsequent midge mediation within Esthwaite Water, UK. Arch Hydrobiol 167:317-334

Deines P, Grey J, Richnow HH, Eller G (2007) Linking larval chironomids to methane: seasonal variation of the microbial methane cycle and chironomid $\delta^{13} \mathrm{C}$. Aquat Microb Ecol 46:273-282

Dubilier N, Giere O, Distel DL, Cavanaugh CM (1995) Characterization of chemoautotrophic bacterial symbionts in a gutless marine worm (Oligochaeta, Annelida) by phylogenetic 16s rRNA sequence analysis in in situ hybridization. Appl Environ Microbiol 61:2346-2350

Egert M, Lemke T, Wagner B, Brune A, Friedrich MW (2003) Microbial community structure in midgut and hindgut of the humus-feeding larva of Pachnoda phippiata (Coleoptera: Scarabaeidae). Appl Environ Microbiol 69: 6659-6668

Eller G, Stubner S, Frenzel P (2001) Group-specific 16S rRNA targeted probes for the detection of type I and type II methanotrophs by fluorescence in situ hybridisation. FEMS Microbiol Lett 198:91-97

France RL, Schlaepfer MA (2000) C-13 and N-15 depletion in components of a foodweb from an ephemeral boreal wetland compared to boreal lakes: putative evidence for microbial processes. Hydrobiologia 439:1-6

Freeman KH, Hayes JM, Trendel JM, Albrecht P (1990) Evidence from carbon isotope measurements for diverse origins of sedimentary hydrocarbons. Nature 343:254-256

Frenzel P (1990) The influence of chironomid larvae on sediment oxygen microprofiles. Arch Hydrobiol 119:427-437

Fuchs G, Thauer R, Ziegler H, Stichler W (1979) Carbon isotope fractionation by Methanobacterium thermoautotrophicum. Microbiology 120:135-139

Goedkoop W, Sonesten L, Markensten H, Ahlgren G (1998) Fatty acid biomarkers show dietary differences between dominant chironomid taxa in Lake Erken. Freshw Biol 40: 135-143

Granéli W (1979) Influence of Chironomus plumosus larvae on the oxygen uptake of sediment. Arch Hydrobiol 87: 385-403

Grey J (2002) A chironomid conundrum: queries arising from stable isotopes. Verh Int Ver Limnol 28:102-105

Grey J, Deines P (2005) Differential assimilation of methanotrophic and chemoautotrophic bacteria by lake chironomid larvae. Aquat Microb Ecol 40:61-66

Grey J, Kelly A, Jones RI (2004a) High intraspecific variability in carbon and nitrogen stable isotope ratios of lake chironomid larvae. Limnol Oceanogr 49:239-244

Grey J, Kelly A, Ward S, Sommerwerk N, Jones RI (2004b) Seasonal changes in the stable isotope values of lakedwelling chironomid larvae in relation to feeding and life cycle variability. Freshw Biol 49:681-689

Hackstein JH, Stumm CK (1994) Methane production in terrestrial arthropods. Publ Nebraska Acad Sci 91:5441-5445

Hanson RS, Hanson TE (1996) Methanotrophic bacteria. Microbiol Rev 60:439-470

Henckel T, Friedrich M, Conrad R (1999) Molecular analyses of the methane-oxidizing microbial community in rice 
field soil by targeting the genes of the 16S rRNA, particulate methane monooxygenase, and methanol dehydrogenase. Appl Environ Microbiol 65:1980-1990

Hollander DJ, Smith MA (2001) Microbially mediated carbon cycling as a control on the $\delta^{13} \mathrm{C}$ of sedimentary carbon in eutrophic Lake Mendota (USA): new models for interpreting isotopic excursions in the sedimentary record. Geochim Cosmochim Acta 65:4321-4337

House CH, Schopf JW, Stetter KO (2003) Carbon isotopic fractionation by archaeans and other thermophilic prokaryotes. Org Geochem 34:345-356

Jahnke LL, Summons RE, Hope JM, des Marais DJ (1999) Carbon isotopic fractionation in lipids from methanotrophic bacteria. II: The effects of physiology and environmental parameters on the biosynthesis and isotopic signatures of biomarkers. Geochim Cosmochim Acta 63:79-93

Johnson RK (1985) Feeding efficiencies of Chironomus plumosus (L.) and C. anthracinus Zett. (Diptera: Chironomidae) in mesotrophic Lake Erken. Freshw Biol 15:605-612

Johnson RK, Boström B, van de Bund W (1989) Interactions between Chironomus plumosus (L.) and the microbial community in surficial sediments of a shallow, eutrophic lake. Limnol Oceanogr 34:992-1003

Jones RI, Grey J, Sleep D, Arvola L (1999) Stable isotope analysis of zooplankton carbon nutrition in humic lakes. Oikos 86:97-104

Kajan R, Frenzel P (1999) The effect of chironomid larvae on production, oxidation and fluxes of methane in a flooded rice soil. FEMS Microbiol Ecol 28:121-129

Kane MD, Poulsen LK, Stahl DA (1993) Monitoring the enrichment and isolation of sulfate-reducing bacteria by using oligonucleotide hybridisation probes designed from environmentally derived 16S rRNA sequences. Appl Environ Microbiol 59:682-686

Kelly A, Jones RI, Grey J (2004) Stable isotope analysis provides fresh insights into dietary separation between Chironomus anthracinus and C. plumosus. J North Am Benthol Soc 23:287-296

Kiyashko SI, Narita T, Wada E (2001) Contribution of methanotrophs to freshwater macroinvertebrates: evidence from stable isotope ratios. Aquat Microb Ecol 24:203-207

Kiyashko SI, Imbs AB, Narita T, Svetashev VI, Wada E (2004) Fatty acid composition of aquatic insect larvae Stictochironomus pictulus (Diptera: Chironomidae): evidence of feeding upon methanotrophic bacteria. Comp Biochem Physiol 139:705-711

Klappenbach JL, Saxman PR, Cole JR, Schmidt TM (2001) rrndb: the ribosomal RNA operon copy number database. Nucleic Acids Res 29:181-184

Kohzu A, Kato C, Iwata T, Kishi D, Murakami M, Nakano S, Wada E (2004) Stream food web fueled by methanederived carbon. Aquat Microb Ecol 36:189-194

Lee RW, Childress JJ (1994) Assimilation of inorganic nitrogen by marine invertebrates and their chemoautotrophic and methanotrophic symbionts. Appl Environ Microbiol 60:1852-1858

Lennon JT, Faiia AM, Feng X, Cottingham KL (2006) Relative importance of $\mathrm{CO}_{2}$ recycling and $\mathrm{CH}_{4}$ pathways in lake

Editorial responsibility: Lars Tranvik,

Uppsala, Sweden food webs along a dissolved organic carbon gradient. Limnol Oceanogr 51:1602-1613

Lüders T, Manefield M, Friedrich MW (2004) Enhanced sensitivity of DNA- and rRNA-based stable isotope probing by fractionation and quantitative analysis of isopycnic centrifugation gradients. Environ Microbiol 6:73-78

Ludwig W, Strunk O, Westram R, Richter L and 28 others (2004) ARB: a software environment for sequence data. Nucleic Acids Res 32:1363-1371

McLachlan AJ (1977) Some effects of tube shape on the feeding of Chironomus plumosus L. (Diptera: Chironomidae). J Anim Ecol 46:139-146

Muyzer G, De Waal EC, Uitterlinden AG (1993) Profiling of complex microbial populations by denaturing gradient gel electrophoresis analysis of polymerase chain reactionamplified genes coding for 16S rRNA. Appl Environ Microbiol 59:695-700

Pernthaler A, Pernthaler J, Amann R (2002) Fluorescence in situ hybridization and catalyzed reporter deposition for the identification of marine bacteria. Appl Environ Microbiol 68:3094-3101

Phillips DL, Gregg JW (2001) Uncertainty in source partitioning using stable isotopes. Oecologia 128:171-179 (see also Erratum, Oecologia 128:304)

Schmitt-Wagner D, Friedrich MW, Wagner B, Brune A (2003) Phylogenetic diversity, abundance, and axial distribution of microorganisms in the intestinal tract of two soil-feeding termites (Cubitermes spp.). Appl Environ Microbiol 69: 6007-6017

Schwarz MVJ, Frenzel P (2005) Methanogenic symbionts of anaerobic ciliates and their contribution to methanogenesis in an anoxic rice field soil. FEMS Microbiol Ecol 52:93-99

Stewart FJ, Newton ILG, Cavanaugh CM (2005) Chemosynthetic endosymbioses: adaptations to oxic-anoxic interfaces. Trends Microbiol 13:439-448

Stief P, de Beer D (2002) Bioturbation effects of Chironomus riparius on the benthic $\mathrm{N}$-cycle as measured using microsensors and microbiological assays. Aquat Microb Ecol 27: 175-185

Stief P, Eller G (2006) The gut microenvironment of sedimentdwelling Chironomus plumosus larvae as characterised with $\mathrm{O}_{2}, \mathrm{pH}$, and redox microsensors. J Comp Physiol B 176:673-683

Summons R, Jahnke LL, Roksandic Z (1994) Carbon isotopic fractionation in lipids from methanotrophic bacteria: relevance for interpretation of the geochemical record of biomarkers. Geochim Cosmochim Acta 58:2853-63

Svensson JM (1997) Influence of Chironomus plumosus larvae on ammonium flux and denitrification (measured by acetylene blockage- and the isotope pairing-technique) in eutrophic lake sediment. Hydrobiologia 346:157-168

Weisburg WG, Barns SM, Pelletier DA, Lane DJ (1991) 16S ribosomal DNA amplification for phylogenetic study. J Bacteriol 173:697-703

Yang H, Schmitt-Wagner D, Stingl U, Brune A (2005) Niche heterogeneity determines bacterial community structure in the termite gut (Reticulitermes santonensis). Environ Microbiol 7:916-932

Submitted: August 17, 2006; Accepted: December 11, 2006 Proofs received from author(s): March 7, 2007 